\title{
KONSTRUKSI SEKSUALITAS PEREMPUAN DALAM KEINDAHAN DAN KESEDIHAN KARYA YASUNARI KAWABATA
}

\author{
Agung Pranoto \& Rini Damayanti \\ Universitas Wijaya Kusuma Surabaya \\ Jl. Dukuh Kupang XXV / 54 Kota Surabaya, Indonesia \\ Pos-el : agungpranotouwks@gmail.com, rinidamayanti0110@gmail.com
}

\begin{abstract}
This research examines the construction of female sexuality in the novel the beauty and sorrow of the works of Yasunari Kawabata. This research is qualitative research that does study of novel the beauty and sorrow of the works of Yasunari Kawabrata. The method used is the deskiptif method that is collecting data, clarification of data, manipulate data, and interpret the data in accordance with the theory that was used at the time the research was conducted. In the novel the beauty and sorrow of the works of Yasunari Kawabata, reflecting the construction of female sexuality. The construction of female sexuality that, first, the novel represents the female body through the figures. The representation of the female body in the text of the novel disegmentasikan by displaying the marker women sexy. Second, the representation of female sexual desire in the novel beauty and Sadness is presented through the desire character Otoko and Keiko to transmit sexual desires with her partner. Third, representations of female sexuality in the relation of beauty and sadness, by Yasunari Kawabata was still predominantly on the male as the subject.
\end{abstract}

Keywords: construction, sexuality

\begin{abstract}
Abstrak
Penelitian ini menelaah konstruksi seksualitas perempuan dalam novel Keindahan dan Kesedihan karya Yasunari Kawabata. Penelitian ini merupakan penelitian kualitatif yang melakukan kajian terhadap novel Keindahan dan Kesedihan karya Yasunari Kawabrata. Metode yang digunakan adalah metode deskiptif yaitu mengumpulkan data, klarifikasi data, mengolah data, dan menafsirkan data sesuai dengan teori yang digunakan pada waktu penelitian dilakukan. Di dalam novel Keindahan dan Kesedihan karya Yasunari Kawabata, mencerminkan konstruksi seksualitas perempuan. Konstruksi seksualitas perempuan tersebut, pertama, novel tersebut banyak merepresentasikan tubuh perempuan melalui tokoh. Representasi tubuh perempuan dalam teks novel ini disegmentasikan dengan menampilkan penanda perempuan seksi. Kedua, representasi hasrat seksual perempuan dalam novel Keindahan dan Kesedihan dimunculkan melalui keinginan tokoh Otoko dan Keiko untuk menyalurkan hasrat seksual dengan
\end{abstract}


pasangannya. Ketiga, representasi relasi seksualitas perempuan dalam Keindahan dan Kesedihan, oleh Yasunari Kawabata masih didominasi pada laki-laki sebagai subjek.

Kata Kunci : konstruksi, seksualitas

\section{PENDAHULUAN}

Teks sastra banyak yang merekonstruksi tubuh dan seksualitas perempuan. Rekonstruksi tubuh dan seksualitas perempuan akhir-akhir ini tidak hanya dilakukan oleh penulis laki-laki. Penulis perempuan akhirakhir ini tidak lagi merasa 'jijik' ketika harus mengonstruksi persoalan tubuh, hasrat seksual, maupun relasi seksual perempuan (pinjam istilah Pakasi, 2007) ke dalam karyanya. Penulis perempuan telah memberikan wacana baru mengenai posisi perempuan di masyarakat. Perempuan selama ini dianggap tidak berhak untuk menyuarakan potensi seksual tubuh mereka, tetapi para penulis ini telah menawarkan satu pandangan baru, bahwa seks juga milik perempuan.

Arivia (2003) menyatakan bahwa kebanyakan perempuan tidak menyadari bahwa tubuh perempuan adalah milik perempuan, sehingga mereka menganggap tubuh mereka sebagai "sesuatu" yang sangat asing bagi mereka sendiri. Oleh sebab itu, perempuan harus mampu menulis nilai dan keindahan melalui tubuh mereka. Perempuan juga harus mampu menciptakan puitika yang sanggup menghancurkan partisi, kelas, dan retorika. Mereka harus menyelam, membelah, melampaui wacana terbalik, yang tertinggi, termasuk wacana yang seakan menertawakan kesunyian dan ketulusan hatinya.

Perempuan mengalami otoritas atas tubuhnya sebagai sesuatu yang estetis. "Tubuh perempuan yang estetis selalu menarik untuk dieksplorasi daripada tubuh laki-laki" (Sukeni, 2011:302), apalagi yang mengeksplorasi kaum perempuan sendiri. Mungkin hal inilah yang mendasari Irigaray dalam tulisannya yang berjudul When Our Lips Speak Together berusaha mengembalikan tubuh perempuan kepada tempatnya "semula" sebelum patriarki, (termasuk juga) wacana di luar perempuan yang membungkus tubuh perempuan ke dalam kategori-kategori sosial yang diciptakan budaya patriarki/lakilaki (Prabasmoro, 2007:42).

Berdasarkan uraian tersebut, tulisan ini juga akan menelaah konstruksi seksualitas perempuan dalam novel Keindahan dan Kesedihan karya Yasunari Kawabata. Novelis 
Jepang yang telah meraih hadiah Nobel 1968 ini, dalam novel tersebut, ia mampu menyuguhkan sajian novel yang puitik, menarik dengan segala macam problematika kehidupan percintaan, sehingga menarik pula bila novel tersebut dikaji dari berbagai sudut pandang. Yasunari Kawabata adalah pengarang laki-laki. Meskipun ia pengarang laki-laki, ia mampu mengilustrasikan tubuh, hasrat, dan seksualitas perempuan secara menarik. Ilustrasi tubuh, hasrat, dan seksualitas perempuan tersebut dilekatkan melalui tokoh-tokoh perempuan, di antaranya adalah Otoko dan Keiko.

\section{Sesuai dengan latar} belakang tersebut, permasalahan dalam tulisan ini adalah konstruksi seksualitas perempuan dalam novel Keindahan dan Kesedihan karya Yasunari Kawabata. Berdasarkan permasalahan umum tersebut, konstruksi seksualitas perempuan mencakup (1) tubuh, (2) hasrat, dan (3) relasi seksualitas. Oleh sebab itu, permasalahan tersebut dapat dirumuskan sebagai berikut:

1) Bagaimana representasi tubuh perempuan dalam novel Keindahan dan Kesedihan karya Yasunari Kawabata?

2) Bagaimana representasi hasrat seksual perempuan dalam novel Keindahan dan Kesedihan karya Yasunari Kawabata?

3) Bagaimana representasi relasi seksualitas perempuan dalam novel Keindahan dan Kesedihan karya Yasunari Kawabata?

Tubuh, Hasrat, dan Relasi Seksualitas Perempuan

Kajian aspek tubuh, hasrat, dan relasi seksualitas perempuan bertolak pada konsep Barthes tentang analisis semiotik. Barthes (2004) memahami idiologi sebagai kesadaran palsu yang membuat orang hidup di dalam dunia imajiner. Idiologi ada selama kebudayaan ada, dan konotasi sebagai ekspresi budaya. Semiotika digunakan untuk memahami konstruksi seksualitas perempuan. Dalam hal ini Ang (1996) mencontohkan kerangka kerja semiotik dapat membantu memahami cara penyajian teks dalam membangun berbagai definisi budaya tentang feminitas dan maskulinitas yang sering bertentangan, yang memberi ruang pada pembaca untuk membangun relasi penuh makna dengan teks yang dibaca.

\section{Representasi Tubuh Perempuan}

Teks menyajikan tubuh perempuan. Tubuh perempuan sering disajikan dalam wujud yang erotis. Pola yang muncul dalam teks ini adalah tubuh perempuan yang disegmentasikan, antara lain, wajah, bibir, dada yang padat berisi, kaki yang jenjang, kulit, dan sebagainya (Pakasi, 2007:1819).

Tubuh tidak dapat dilihat sebagai fenomena biologis semata, melainkan juga dibentuk, 
dibatasi, dan dirumuskan oleh masyarakat (Shiling, 1996). Menurut Bourdieu (dalam Shiling, 1996) tubuh adalah "penerima nilai-nilai simbolik dan fenomena materi yang membentuk dan dibentuk oleh masyarakat". Foucault (dalam Shiling, 1996) juga memandang bahwa tubuh sebagai objek pengaturan wacana. Di pihak lain Cornnell (dalam Shiling, 1996) berpendapat bahwa "tubuh yang dikonstruksi secara sosial berdasarkan jender adalah bagian luar tubuh, yaitu konstruksi bentuk dan ukuran". Cornnell berargumen bahwa ketimpangan dalam masyarakat terutama didasari oleh kriteria yang ditentukan secara sosial terhadap tubuh. Melalui tubuh pula manusia diajari untuk melihat perbedaan antar jenis kelamin, misalnya melalui perbedaan pakaian dan pelbagai stereotip yang mengunggulkan laki-laki secara fisik.

Piliang (2004) sependapat dengan pemikiran Bourdieu yang menyatakan bahwa tubuh perempuan merupakan arena permainan tanda yang bisa dipertukarkan dengan istilah political economy of the body signs. Dalam konteks ini misalnya, tubuh perempuan seperti wajah, dada, kulit, kaki, pantat ditujukan untuk membangun citra tubuh perempuan yang seksi. Nilai tubuh perempuan dieksplorasi menjadi permainan tanda yang membangun makna tertentu, misalnya seksi, menantang, maupun bergairah bagi lawan jenisnya.

\section{Representasi Hasrat Seksual Perempuan}

Pakasi (2007) berpendapat bahwa hasrat perempuan yang terbangun dalam teks adalah hasrat mendapatkan cinta dan romantisme dari pasangannya. Hasrat tersebut terbentuk berdasarkan jender. Perempuan menghasratkan cinta, sedangkan laki-laki menghasratkan kenikmatan. Di sisi lain, ada juga kontradiksi dalam teks yang juga menampilkan hasrat seks perempuan demi kenikmatan perempuan itu sendiri dan dilakukan melalui aktivitas seksual yang secara sadar ia lakukan atas keinginannya sendiri. Di dalam teks, perempuan sesungguhnya bebas menyatakan keinginan seksnya, tetapi hal tersebut akan menjadikan perempuan objek fantasi laki-laki.

\section{Representasi Relasi Seksual Perempuan}

Teks

cenderung menampilkan seksualitas perempuan sebagai objek seks laki-laki (Pakasi, 2007). Barthes (2004) menanggapi hal itu sebagai idiologi tersembunyi yang terpantul dalam teks. Idiologi yang menempatkan perempuan sebagai objek seks dapat dijelaskan melalui mitos. Mitos merupakan sistem komunikasi, yaitu pesan yang terdiri atas tanda-tanda. Idiologi 
objektivikasi tubuh perempuan beroperasi melalui tanda-tanda.

$$
\text { Idiologi objektivikasi }
$$

tubuh perempuan terlihat jelas pada teks yang melakukan fragmentasi terhadap tubuh perempuan: dada, mata, kulit, kaki, dan sebagainya. Fragmentasi ini mereduksi perempuan dan mendepersonalisasi bagian tubuh perempuan untuk kepentingan kepuasan laki-laki. Teks itu menampilkan tubuh perempuan sebagai objek hasrat laki-laki demi kekuasaan dan dominasi seksual laki-laki terhadap perempuan (Pakasi, 2007). Penyajian yang mengobjekkan perempuan disebut sebagai thanatica representation, yaitu penyajian yang memperlakukan perempuan sebagai objek dan mereproduksi dominasi laki-laki.

Teks juga masih secara ambigu mengontraskan hasrat seksual laki-laki dan perempuan. Menurut Pakasi (2007) penampilan hasrat seksual perempuan yang aktif lebih ditujukan untuk memuaskan fantasi pembaca teks laki-laki. Namun teks juga dapat menampilkan perlawanan perempuan untuk keluar dari objektivikasi laki-laki. Dalam konteks ini, teks merupakan pertarungan makna. Teks tidak menyajikan satu makna, tetapi ada beragam makna yang dapat saling bertentangan dan berkompetisi satu sama lain.

Dalam teks sebenarnya masih ada ruang bagi perempuan untuk melunakkan objektivikasi tubuh dan hasratnya. Dalam konteks ini dapat dijelaskan pula bahwa perempuan dapat mengubah posisi dari objek menjadi subjek. Dengan demikian bahwa relasi seksual dalam teks itu bisa objek-subjek atau sebaliknya subjek-objek, suatu relasi yang saling bergantian.

\section{METODE PENELITIAN}

Penelitian

ini menggunakan pendekatan kualitatif. Penelitian ini menggunakan metode deskriptif kualitatif. Deskriptif kualitatif merupakan suatu penelitian dengan penggambaran melalui kata-kata atau kalimat untuk memperoleh suatu kesimpulan. Penelitian ini merupakan penelitian kualitatif yang melakukan kajian terhadap novel Keindahan dan Kesedihan karya Yasunari Kawabrata. Metode yang digunakan adalah metode deskiptif yaitu mengumpulkan data, klarifikasi data, mengolah data, dan menafsirkan data sesuai dengan teori yang digunakan pada waktu penelitian dilakukan.

Dalam penelitian ini yang menjadi sumber data adalah novel Keindahan dan Kesedihan karya Yasunari Kawabrata terbitan Jalasutra. Dengan 256 jumlah halaman. Data penelitian ini berupa kutipan-kutipan yang terdapat dalam novel Keindahan dan Kesedihani karya Yasunari 
Kawabrata, kutipan yang berhubungan dengan rumusan masalah

Sesuai dengan penelitian kualitatif, teknik pengumpulan data dalam penelitian ini adalah analisis dokumentasi. Analisis dokumentasi dilakukan untuk mengumpulkan data yang bersumber dari arsip dan dokumen yang ada hubungannya dengan penelitian. Dokumen sebagai sumber data dimanfaatkan untuk menguji, menafsirkan, serta meramalkan.

Penelitian ini dilakukan dengan langkah-langkah pengumpulan data sebagai berikut. (1) Membaca novel Keindahan dan Kesedihan karya Yasunari Kawabrata.

Mencatat data yang beraitan dengan representasi seksual atau data dalam novel Keindahan dan Kesedihan karya Yasunari Kawabrata (3) Menerapkan data yang berupa kutipan-kutipan kedalam paragraf yang berkenaan dengan rumusan masalah tersebut.

\section{HASIL PENELITIAN DAN PEMBAHASAN \\ Konstruksi Seksualitas \\ Perempuan dalam Keindahan dan Kesedihan}

Konstruksi seksualitas perempuan dalam novel Keindahan dan Kesedihan karya Yasunari Kawabata, sesuai dengan permasalahan dan ancangan teori yang dibahas sebelumnya terpilah menjadi tiga bagian, yaitu (1) representasi tubuh perempuan, representasi hasrat seksual perempuan, dan (3) representasi relasi seksual perempuan. Analisis dan pembahasan ketiga hal tersebut dideskripsikan sebagai berikut.

\section{Representasi Tubuh Perempuan dalam Keindahan dan Kesedihan}

Pemerian tubuh perempuan dalam teks dibangun dengan menempatkan pembaca seakan-akan menonton tubuh. Objektivikasi tubuh perempuan dalam teks yang terkesan dibuat erotis dan hal ini secara seksual dianggap oleh laki-laki menarik. Tubuh perempuan menyiratkan seni yang indah dengan segala lekuk-lekuknya. Dalam konteks tubuh ini tidak bisa dipungkiri menempatkan perempuan pada posisi tersubordinasi oleh lakilaki.

Dalam novel Keindahan dan Kesedihan, Yasunari Kawabata berkali-kali menampilkan tubuh perempuan. Representasi tubuh perempuan dalam teks novel tersebut, tidak ada satu pun yang menyentuh organ genital perempuan seperti vagina maupun klitoris. Representasi tubuh perempuan di antaranya dapat dibaca dalam kutipan berikut.

\begin{tabular}{lr}
\multicolumn{2}{c}{ "Bukan. Tokyo. } \\
Tetapi saya jatuh cinta \\
dengan & karya-karya \\
Nona Ueno dan datang \\
kemari
\end{tabular}




mengejarnya, akhirnya
dia mengajak saya untuk
tinggal bersamanya."
Oki menatap wajah sang
gadis. Sewaktu dia
berbicara padanya di
hotel, dia tidak sempat
menyadari
kecantikannya, tetapi
sekrang dia melihat
betapa cantik raut wajah
gadis itu. Dia memiliki
leher yang jenjang dan
cuping telinga yang
menawan. Semua itu
berpadu serasi. Dia
memang cantik...."

(Kawabata, 2006:39).

Kutipan tersebut merupakan representasi tubuh Otoko. Otoko oleh Oki dinilai memiliki wajah yang cantik, leher yang jenjang, dan cuping telinga yang menawan. Pemerian Oki terhadap tubuh Otoko yang seperti itu melukiskan adanya nilai lebih dalam diri tokoh Otoko. Bagi Oki, sesuai dengan pengakuannya bahwa, "Otoko dalam kenangannya adalah perempuan paling menggairahkan yang pernah dia kenal" (Kawabata, 2006:38).

Perempuan selalu menjadi objek tatapan mata laki-laki. Raut wajah yang cantik, leher yang jenjang, dan cuping yang menawan disegmentasikan dan diberi kode-kode seksual sebagai penanda tubuh yang seksi. Beberapa penanda keseksian itu dimunculkan oleh pengarang telah menyita waktu pada pembaca untuk membayangkan kencantikan yang mendalam pada tokoh Otoko. Secara konotatif penggambaran sisi fisik tokoh Otoko merupakan representasi tubuh yang bisa membangkitkan gairah laki-laki.

\section{Representasi Hasrat Seksual Perempuan dalam Keindahan dan Kesedihan}

Hasrat seksual tidak hanya menjadi dominasi laki-laki. Perempuan pun memiliki hasrat seksual pula untuk pemenuhan kenikmatan dirinya. Walaupun kenyataan secara biologis lakilaki dan perempuan memiliki hasrat seksual, namun fakta menunjukkan bahwa hasrat seksual laki-laki cenderung lebih ditampakkan dan hasrat seksual perempuan cenderung tidak ditampakkan.

Dalam novel Keindahan dan Kesedihan, Yasunari Kawabata juga menampilkan hasrat seksual perempuan. Representasi hasrat seksual perempuan dalam teks novel tersebut, di antaranya secara eksplisit dapat dibaca dalam kutipan berikut.

"Saat seorang
perempuan memutuskan
untuk menikahi seorang
novelis, hal semacam itu
tak bisa dihindari. Jika
kamu harus
mengkhawatirkan
seseorang, maka ia adalah
Otoko."Selama masa
pemulihan, kulit Fumiko
tampak bercahaya dan
ayu. Apakah itu
keajaiban masa muda?




$\begin{array}{lr}\text { Bahkan } & \text { hasrat } \\ \text { perempuan } & \text { itu terhadap } \\ \text { suaminya } & \text { semakin } \\ \text { hebat." } & \text { (Kawabata, } \\ \text { 2006:63). } & \end{array}$

Hasrat seksual tokoh Fumiko kepada suaminya, Oki, dalam kutipan narasi tersebut dinyatakan secara eksplisit. Penggambaran hasrat perempuan yang demikian itu menunjukkan bahwa perempuan telah memosisikan sebagai subjek. Dalam konteks kutipan tersebut Fumiko sebagai subjek dan Oki sebagai objek.

Hasrat seksual dimiliki
setiap orang, baik laki-lak
maupun perempuan. Hasrat seksual itu merupakan hal yang melekat pada diri manusia sejak mereka dilahirkan. Selain itu, hasrat seksual tersebut merupakan kebutuhan biologis yang tidak bisa dielakkan antara laki-laki dan perempuan.

Hasrat seksual bagi perempuan kadang-kadang timbul setelah ada sentuhan dari laki-laki, terutama laki-laki yang dicintai. Dengan sentuhan yang lembut dan romantis, perempuan akan merasakan ada dorongan yang memunculkan hasrat seksual. Perhatikan kutipan berikut.

"Sakiti juga aku,"
katanya. Oki menatap
lengannya-benar-benar
seorang gadis belia--dan
tangannyar mulai
menjelajah ujung jemari

sampai bahunya. Otoko menggeliat nikmat." (Kawabata, 2006:55).

$\begin{array}{ccr}\text { Dalam } & \text { kutipan } & \text { tersebut } \\ \text { tampak } & \text { bahwa } & \text { Otoko } \\ \text { "menggeliat } & \text { nikmat" } & \text { setelah }\end{array}$
merasakan sentuhan tangan Oki yang menjelajah sampai bahu Otoko. Hal itu berarti bahwa dalam diri Otoko telah muncul hasrat seksual. Hasrat seksual Otoko timbul karena Oki sebenarnya merupakan laki-laki yang dicintainya.

\section{Representasi Relasi Seksual Perempuan dalam Keindahan dan Kesedihan}

Relasi seksual dapat dimaknai sebagai wujud relasi kesalingbergantian antara lakilaki dan perempuan memperoleh kenikmatan seksual. Selain itu, relasi seksual juga bisa ditafsirkan sebagai siapa yang mendahului dan siapa yang didahului atau relasi antara subjek-objek dan sebaliknya.

Secara umum teks sastra cenderung menampilkan seksualitas perempuan sebagai objek seks laki-laki. Dalam novel Keindahan dan Kesedihan karya Yasunari Kawabata ini relasi seksualitas lebih dominan lakilaki daripada perempuan. Lakilaki melalui tokoh Oki cenderung sebagai subjek dan tokoh Otoko maupun Keiko cenderung menjadi objek seks. Meski demikian, di dalam novel ini, dalam sebuah narasi juga ada yang mendeskripsikan relasi 
seksualitas perempuan melalui tokoh Otoko yang meregang nikmat dalam persetubuhannya dengan Oki.

\section{Kutipan}

berikut

merepresentasikan relasi seksual laki-laki melalui tokoh Oki sebagai subjek dan Otoko sebagai objek.

Saat itu perempuan itu baru berumur lima belas tahun dan itu merupakan kata-kata pertamanya setelah Oki merenggut

keperawanannya. Oki sendiri belum berkata apa-apa. Tak ada kata yang bisa dia ucapkan. Dia memeluknya erat dengan penuh kelembutan, membelai rambutnya, tetapi dia tidak bisa mengucapkan sepatah kata pun. Kemudian Otoko melepaskan tangan Oki dari tubuhnya dan mulai berpakaian. Oki bangkit, memakai kemejanya dan mulai mengikat dasinya. Otoko menatap wajahnya, sepasang matanya basah dan bercahaya, tetapi bukan karena tangisan. Oki menghindari tatapan matanya. Bahkan ketika dia mengecup gadis itu, selekasnya, sepasang mata Otoko tetap terbuka lebar sampai Oki membuatnya terpejam dengan kecupan bibirnya. (Kawabata, 2006:28).

Kutipan tersebut merepresentasikan relasi seksual yang menempatkan tokoh Oki sebagai subjek. Otoko yang masih usia lima belas tahun, sebagai objek, telah direnggut keperawanannya oleh Oki. Dalam konteks ini tampak bahwa dominasi relasi seksual ada pada tokoh laki-laki.

Di sisi lain, dalam hubungan seksual antara Oki dengan Otoko, ternyata Otoko memperoleh kenikmatan seks. Kenikmatan seks yang dirasakan Otoko itu juga membalik posisi Otoko sebagai subjek. Perhatikan kutipan berikut.

$$
\begin{aligned}
& \text { "Mungkin hal itu } \\
& \text { menjelaskan nafsu buta } \\
& \text { yang tak pernah } \\
& \text { terpuaskan. Saat ia } \\
& \text { meregang nikmat dan } \\
& \text { menggigit bahu pria itu, } \\
& \text { ia bahkan tidak } \\
& \text { menyadari bahwa darah } \\
& \text { kesuciannya telah } \\
& \text { mengalir". (Kawabata, } \\
& \text { 2006:154). }
\end{aligned}
$$

Kutipan tersebut secara implisit merepresentasikan relasi seksual perempuan melalui tokoh Otoko. Relasi seksual perempuan terjadi setelah Otoko merasakan kenikmatan seksual yang pertama kali ia peroleh dari Oki. Pada saat Otoko dilukiskan 'menggigit bahu pria (Oki) itu', berati posisi Otoko yang semua 
menjadi objek berubah menjadi subjek.

\section{SIMPULAN}

Berdasarkan uraian di atas dapat disimpulkan bahwa di dalam novel Keindahan dan Kesedihan karya Yasunari Kawabata, mencerminkan konstruksi seksualitas perempuan. Konstruksi seksualitas perempuan tersebut, pertama, novel tersebut banyak merepresentasikan tubuh perempuan melalui tokoh Otoko dan Keiko dalam jalinan asmaranya dengan Oki dan juga jalinan asmara antara Keiko dengan Taichiro (anak Oki). Representasi tubuh perempuan dalam teks novel ini disegmentasikan dengan menampilkan penanda perempuan seksi, seperti raut muka, leher yang jenjang, alis mata, cuping telinga, paha telanjang, puting payudara yang masih berwarna merah muda, dan lain-lain.

Kedua, representasi hasrat seksual perempuan dalam novel Keindahan dan Kesedihan dimunculkan melalui keinginan tokoh Otoko dan Keiko untuk menyalurkan hasrat seksual dengan pasangannya. Pendeskripsian hasrat seksual perempuan dalam novel ini tidak begitu menonjol bila dibandingkan dengan pendeskripsian hasrat seksual laki-laki. Ketidakmenonjolan dialog maupun narasi tentang hasrat seksual perempuan karena lebih disebabkan oleh kecenderungan perempuan untuk mendapatkan cinta, kasihsayang, dan romantisme dari pasangannya, sementara hasrat seksual laki-laki lebih mengarah pada diperolehnya kenikmatan seksual.

Ketiga, representasi relasi seksualitas perempuan dalam Keindahan dan Kesedihan, oleh Yasunari Kawabata masih didominasi pada laki-laki sebagai subjek. Relasi seksual perempuan sebagai subjek dalam novel ini masih tetap dimunculkan oleh pengarang namun tidak mendominasi. 


\section{DAFTAR PUSTAKA}

Ang, Ien. 1996. Living Room War: Rethinking Media Audience for a Postmodern World. London: Routledge.

Arivia, Gadis. 2003. Filsafat Berperpektif Feminis. Jakarta: Yayasan Jurnal Perempuan.

Barthes, Roland. 2004. Mitologi. Penerjemah Nurhadi dan A. Sihabull Millah. Yogyakarta: Kreasi Wacana.

Kawabata, Yasunari. 2006. Keindahan dan Kesedihan. Penerjemah: Sobar Hartini. Yogyakarta: Jalasutra.

Pakasi, Diana Teresa. 2007. "Tubuh, Hasrat, Relasi: Konstruksi Seksualitas Perempuan dalam Majalah Laki-laki", dalam Pola dan Silangan Jender dalam Teks Indonesia. Lisabona Rahman (Penyunting). Jakarta: Yayasan Kalam.

Piliang, Yasraf Amir. 2004. Hipersemiotika: Tafsir Cultural Studies atas Matinya Makna. Yogyakarta: Jalasutra.

Prabasmoro, Aquarini Priyatna. 2007. Kajian Budaya Feminis (Tubuh, Sastra dan Budaya Pop). Yogyakarta: Jalasutra.

Shilling, Christ. 1996. The Body and Social Theory. London: Sage Publication.
Sukeni, Ni Nyoman. 2011. Otonomi Tubuh Perempuan; cf Jelajah Kajian Budaya (Exploring Cultural Studies). Denpasar: Pustaka Larasan. 